Tropical Journal of Pharmaceutical Research April 2010; 9 (2): 119-125

(C) Pharmacotherapy Group,

Faculty of Pharmacy, University of Benin

Benin City, 300001 Nigeria.

All rights reserved.

Research Article

Available online at http://www.tjpr.org

\title{
Physicochemical Analysis of the Aqueous Extracts of Six Nigerian Medicinal Plants
}

\section{Sunday J Ameh*, Florence Tarfa, Taoheed M Abdulkareem, Martha C Ibe, Cordelia Onanuga, and Obiageri O Obodozie}

Department of Medicinal Chemistry and Quality Control, National Institute for Pharmaceutical Research and Development (NIPRD), PMB 21, Garki, Idu Industrial Area, Abuja, Nigeria.

\begin{abstract}
Purpose: Extracts of Picralima nitida seeds, Detarium microcarpum stem bark, Aframomum melagueta seeds, Terminalia catappa leaves, Acacia nilotica pods, and Morinda lucida stem bark, are under consideration for development into suitable dosage forms for treating diabetes mellitus, sickle cell anemia and malaria. This study aimed at evaluating the extracts for features that would influence decisions on them in the course of the project.

Methods: Physicochemical determinations, including proximate analysis, were done by sensory examination, and gravimetric and electrochemical techniques. Thin layer chromatography was carried out with normal silica plates using various solvent systems. Metallic content analyses were carried out by atomic absorption spectroscopy.

Results: The extracts were dry but hygroscopic, with a loss on drying range of $0.26-12.00 \% \mathrm{w} / \mathrm{w}$. The $\mathrm{pH}$ of the $5-10 \%$ solutions ranged 5 - 7. No harsh sensory effects, such as lacrimation, were detected in any of the extracts. Total ash ranged from $3.79-20.68 \% \mathrm{w} / \mathrm{w}$, while acid insoluble ash values were below detection. The extracts yielded reproducible chromatograms on normal silica plates developed with various solvent systems. Copper, present at $0.16-0.58 \mathrm{mg} / 100 \mathrm{~g}$, was the lowest occurring microelement while calcium content was highest, at $41-216 \mathrm{mg} / 100 \mathrm{~g}$. The level of lead, a heavy metal, was $0.05-0.22 \mathrm{mg} / 100 \mathrm{~g}$.

Conclusion: The results confirm that the extracts require no special handling, possess characteristics that would allow their possible development into solid dosage forms, and that their lead contents complied with official limits.
\end{abstract}

Keywords: Aqueous extract, Picralima nitida, Detarium microcarpum, Aframomum melagueta, Terminalia catappa, Acacia nilotica, Morinda lucida. 


\section{INTRODUCTION}

The aims of the policy of World Health Organization (WHO) on medicinal plant materials include ascertaining their safety, efficacy and specifications [1]. That policy, which was successfully implemented in the development of Niprisan ${ }^{\circledR}$ at the National Institute for Pharmaceutical Research and Development, Abuja, Nigeria [2], is being considered for application in the development of antidiabetics from the seeds of Picralima nitida (Family: Apocynaceae) and the stem bark of Detarium microcarpum (Family: Fabaceae); antisickling drugs from the seeds of Aframomum melagueta (Family: Zingiberaceae) and the leaves of Terminalia catappa (Family: Combretaceae); and antimalarials from the pods of Acacia nilotica (L. Wild. Ex Delile; Family: Fabaceae) and the root bark of Morinda lucida (Family: Rubiaceae).

The seed of Picralima nitida are rich in alkaloids and are used to treat malaria [3], pyrexia, pain and inflammatory conditions $[4,5]$. Although, a possible hypoglycemic effect has been reported [6] and subsequently confirmed [7] for $N$. nitida, there is no similar report for Detarium microcarpum. Aframomum melegueta is known for its peppery flavour and pungency, which are attributed mainly to aromatic ketones such as 6-paradol [8]. Terminalia catappa leaf contains kaemferol, quercetin, tannins, saponins and phytosterols. The pigments responsible for the colour change (from red to orange) are violaxanthin, lutein and zeaxanthin. The leaf is thought to contain antioxidants and phytochemicals against cancer, chromosome breakage, and sickle cell anaemia $[9,10]$. The pods and roots of Acacia nilotica are known for their demulcent, styptic and astringent properties, and the stem bark is ingested for leucorrheoa, diarrheoa, dysentery, cough and diabetes mellitus type II. The sap or bark, leaves, and young pods are strongly astringent due to tannin. They are chewed in Senegal as an antiscorbutic and as a lactogogue in Ethiopia
[11]. Decoctions of the stem, root, bark and leaves of Morinda lucida are used to treat yellow fever, malaria and trypanosomiasis [12]. In Nigeria, M. lucida is one of the most used traditional medicines against fever. It contains anthraquinones, anthraquinols, tannins, flavonoids and saponosides [13].

Some metals, e.g., sodium, potassium, magnesium and calcium, that are required in relatively large amounts in the body are called macro-elements [14,15]. Other metals, including chromium, manganese, iron, zinc, nickel and copper that are required in smaller or trace amounts are called micro-elements. The presence in food and drugs of metals such as cadmium, mercury and lead, which are injurious to health, is regulated by law. This latter group is called heavy metals $[14,15]$. Plants are a major source of chromium - a requirement in glucose metabolism; iron - a component of haemoglobin; zinc - a mineral required in cell division and protein synthesis and insulin metabolism; nickel - a requirement for active beta-cells of the pancreas [16]; and copper a component of ceruloplasmin, a requirement in the synthesis of haemoglobin $[14,15]$.

Presented in this paper are the results of physicochemical tests on the dry extracts of six plants mentioned above, preparatory to their use in producing suitable dosage forms in accordance with good manufacturing practice (GMP). The possible role of metals in the actions of herbal medicines is also discussed.

\section{EXPERIMENTAL}

\section{Plant materials}

Seeds of Picralima nitida; stem bark of Detarium microcarpum; seeds of Aframomum melagueta; leaves of Terminalia catappa; pods and roots of Acacia nilotica; and stem bark of Morinda lucida, were obtained from within Suleja, Niger State and Abuja, Nigeria, during the months of September and October 2008. They were identified and confirmed by 
Mallam Ibrahim Muazzam, an ethnobotanist at the National Institute for Pharmaceutical Research and Development (NIPRD), Abuja, Nigeria. Voucher samples were preserved in the Institute's Herbarium, with the following voucher numbers: $P$. nitida (TVN-33R-1:9/1008); D. microcarpum (TVN-33R-2:9/10-08); $A$. melagueta (TVN-33R-3:9/10-08); T. catappa (TVN-33R-4:9/10-08); $A$. nilotica (NIPRD/H/ 6245); and M. lucida (NIPRD/H/6279).

\section{Treatment and sampling of plant materials}

All the plant materials were air-dried in the Institute's shade for drying medicinal plant materials, and subsequently comminuted to coarse powder with a grinding machine. The procedure for sampling consists of the following steps as per WHO [17]: Three (3) original samples from each batch or container were combined into a pooled sample and subsequently used to prepare the average sample. The average sample was prepared by "quartering" the pooled sample as follows: each pooled sample was mixed thoroughly, and constituted into a square-shaped heap. The heap was then divided diagonally into 4 equal parts. Any 2 diagonally opposite parts were taken and mixed carefully. This step was repeated as necessary until the required quantity of sample was obtained. Any material remaining was returned to the batch. The final samples were obtained from an average sample by quartering, as described above. This means that an average sample gave rise to 4 final samples. Each final sample was divided into 2 portions. One portion was retained as reference material, while the other was tested in duplicate or triplicate.

\section{Extraction of plant materials}

The extracts were prepared by hot extraction of $200 \mathrm{~g}$ of the plant material, first with $600 \mathrm{ml}$ of boiling water, followed by two successive $200 \mathrm{ml}$ volumes of boiling water. The extracts were subsequently filtered into dishes, and evaporated to dryness on a water bath. When a smaller or larger quantity of material was to be extracted the ratio of the material to water was maintained as above. The dry extracts thus obtained were subjected to the physicochemical tests described below.

\section{Physicochemical tests}

The following tests, briefly described, were carried out on the extracts as per WHO [17]:

\section{Solubility}

This was determined at $20 \stackrel{\circ}{C}$ and expressed in terms of "parts', representing the number of millilitre [ml] of water in which $1 \mathrm{~g}$ of the material is soluble. The following descriptive terms are used: very soluble - less than 1 part; freely soluble - 1 to 10 parts; soluble 30 to 100 parts; sparingly soluble -30 to 100 parts; slightly soluble - 100 to 1000 parts; Very slightly soluble - 1000 to 10,000 parts; and practically insoluble - more than 10,000 parts.

\section{Loss on drying (LOD)}

This was carried out using a minimum of 0.5 $-1.0 \mathrm{~g}$ of material. Drying was effected in a gravity-convention oven (Lindberg/Blue $M$ ) maintained at $105-110{ }^{\circ} \mathrm{C}$. The results are expressed as a range or as mean \pm standard deviation. The LOD results were validated by concurrent determination of the LOD of $\mathrm{CuSO}_{4}$ crystals, which was $36.43 \% \mathrm{w} / \mathrm{w}$.

\section{Total ash (TA) and Acid insoluble ash (AIA)}

These values were determined using a minimum of $0.5-1.0 \mathrm{~g}$ of material and a furnace (Vecstar Furnace) which was heated gradually to the ignition temperature of 650 $700{ }^{\circ} \mathrm{C}$. The process was repeated until at least two consecutive constant weights were obtained. The results are expressed as a range or as a mean value \pm standard deviation. The TA results were validated by concurrent determination of the TA of paracetamol BP, which was less than $0.01 \%$ w/w. 


\section{pH values}

These were determined by means of a $\mathrm{pH}$ meter (Jenway 3505).

\section{Thin layer chromatography}

The procedures and items used were as follows: For the stationary phase, fluorescent, precoated K5 silica plates were used; for the mobile phase, various solvent systems shown in the results were employed; and Shandon TLC Chromatank was used for developing the plates. Solutions of the analytes in ethanol were prepared and applied as follows: To about $1 \mathrm{mg}$ of the analyte, 2 or more drops 2 drops of ethanol were added, and swirled until dissolved (this is equivalent to about $1 \% \mathrm{w} / \mathrm{v}$ solution of the analyte).

The analyte solution was applied to the plate as a $1 \mu \mathrm{l}$ droplet from a microsyringe. The spot was allowed to dry before developing the plate. In order to saturate the chamber of the developing tank with the vapour of the solvent system to be used as mobile phase, the inner surfaces were padded with pieces of filter paper soaked in the solvent. The level of the solvent in the developing tank was adjusted to a level 2 to $3 \mathrm{~mm}$ below the line of origin on the plate. The plate was considered developed when the distance between point of origin and the distance travelled by the solvent front was not less than $3 / 4$ of the length of the plate and no further than $5 \mathrm{~mm}$ below the top of the plate. The plate so developed was allowed to airdry before visualizing, using a viewing cabinet (CAMMAG) and a UV-lamp (CAMMAG - equipped to emit light at 254 or $366 \mathrm{~nm}$ ). The retention factor (Rf) value for a given spot, defined as the distance moved by the spot divided by the distance moved by the solvent front, was calculated for each spot on the plate.

\section{Atomic absorption spectroscopy}

The materials and methods for atomic absorption spectroscopy were as per the British Pharmacopoeia [18] as follows: The equipment consisted of a digestion vessel, made up of a vitreous silica crucible. The materials used were digestion mixtures, made up of 2 parts by weight of nitric acid $(1000 \mathrm{~g} / \mathrm{l})$ and 1 part by weight of perchloric acid $(1170 \mathrm{~g} / \mathrm{l})$, and any two suitable reference materials. Before use, the entire equipment was scrupulously cleaned with nitric acid (1000 $\mathrm{g} / \mathrm{l})$, rinsed with water, and dried at $120{ }^{\circ} \mathrm{C}$. About $250 \mathrm{mg}$ of the airdried, coarsely powdered sample was accurately transferred into a clean silica crucible, followed by the addition of $1.0 \mathrm{ml}$ of the digestion mixture. After covering the crucible, the mixture was placed in an oven, heated slowly to $100{ }^{\circ} \mathrm{C}$ and maintained at this temperature for $3 \mathrm{~h}$; it was further heated to, and kept at $120{ }^{\circ} \mathrm{C}$ for $2 \mathrm{~h}$. Finally, it was heated slowly to, and kept at $240{ }^{\circ} \mathrm{C}$ for $4 \mathrm{~h}$. The digest or residue was dissolved in $2.5 \mathrm{ml}$ of nitric acid $(1000 \mathrm{~g} / \mathrm{l})$ and the atomic absorption spectra of the resulting solution determined with an atomic absorption spectrophotometer (model AAS 969, Unicam), using nitric acid (1000 g/l) as blank solution, and standard lead nitrate solution made with nitric acid $(1000 \mathrm{~g} / \mathrm{l})$ as reference.

\section{Statistical analysis}

The results were expressed as mean \pm standard deviation calculated using Microsoft Excel, 2003 version.

\section{RESULTS}

The sensory and other key features of the extracts that would have a direct bearing on handling and in-process quality control are shown in Tables 1 and 2, respectively.

The TLC characteristics and the levels of metallic constituents of the extracts that would be useful for identification and quality 
Table 1: Characteristics of the dry extracts of six Nigerian medicinal plants

\begin{tabular}{|c|c|}
\hline Aqueous extract & Description \\
\hline P. nitida seed & $\begin{array}{l}\text { Amber granular powder, with a tendency to clump. } \\
\text { Bitter, with a characteristic aroma. Very soluble in water, } \\
\text { and yield a slightly cloudy solution. pH of } 5 \% \text { solution is } 5 \text {. }\end{array}$ \\
\hline D. microcarpum stem bark & $\begin{array}{l}\text { Brown granular powder. Odourless. Sour, as an unripe fruit. } \\
\text { Sparingly soluble in water. } \mathrm{pH} \text { of } 5 \% \text { solution is } 7 \text {. }\end{array}$ \\
\hline A. melagueta seed & $\begin{array}{l}\text { Amber granular powder. Characteristic pungency in smell and taste that } \\
\text { lingers at the tip of the tongue. Soluble in water to yield a slightly cloudy } \\
\text { solution. } \mathrm{pH} \text { of } 5 \% \text { solution is } 5\end{array}$ \\
\hline T. catappa leaf & $\begin{array}{l}\text { Brown granular/ crystalline powder. Practically } \\
\text { odourless. Slightly sour, as an unripe fruit. } \\
\text { Freely soluble in water, yielding a foaming brown solution. } \\
\text { The } \mathrm{pH} \text { of } 5 \% \text { solution is } 6 \text {. }\end{array}$ \\
\hline Acacia nilotica pod & $\begin{array}{l}\text { A damp powder with pleasant aroma. Soluble in water and } \\
\text { yields brownish colloid. } \mathrm{pH} \text { of } 5 \% \text { solution is } 6\end{array}$ \\
\hline Morinda lucida stem bark & $\begin{array}{l}\text { Dark brown, hard and congealed gritty mass, } \\
\text { with an agreeable cocoa-like aroma and taste. } \\
\text { Freely soluble in water. } \mathrm{pH} \text { of } 5 \% \text { solution is } 6\end{array}$ \\
\hline
\end{tabular}

Table 2: Loss on drying (LOD), total ash (TA) and acid-insoluble (AIA) values of the extracts of six Nigerian medicinal plants (mean $\pm S D, n=3$ or 4 )

\begin{tabular}{llll}
\hline \multicolumn{1}{c}{ Extract } & \multicolumn{1}{c}{ LOD $(\% \mathbf{w} / \mathbf{w})$} & \multicolumn{1}{c}{ TA $(\% \mathbf{w} / \mathbf{w})$} & AlA $(\% \mathbf{w} / \mathbf{w})$ \\
\hline P. nitida & $8.01 \pm 0.77$ & $3.79 \pm 2.04$ & Below detection \\
D. microcarpum & $8.89 \pm 0.83$ & $10.26 \pm 1.41$ & Below detection \\
A. melagueta & $11.99 \pm 0.99$ & $20.68 \pm 0.64$ & Below detection \\
T. catappa & $2.23 \pm 0.37$ & $12.52 \pm 0.83$ & Below detection \\
A. nilotica & $3.90 \pm 0.08$ & $10.47 \pm 0.04$ & Below detection \\
M. lucida & $0.26 \pm 0.03$ & $19.65 \pm 0.87$ & Below detection \\
\hline
\end{tabular}

control are shown in Tables 3 and 4 , respectively.

\section{DISCUSSION}

The sensory and related characteristics of the extracts (Table 1) show that they are nonhazardous, and can be handled within normal laboratory or factory conditions. The fact that they can be obtained dry should facilitate handling during production. Dry materials also have the additional advantage of been easier to store and less liable to microbial or hydrolytic spoilage. The LOD results (Table 2) indicate that all the extracts were hygroscopic, with values ranging from about 0.26 to $11.99 \% \mathrm{w} / \mathrm{w}$ with the stem bark of $M$. lucida being the least hygroscopic and the seed extract of $A$. melagueta the highest.
These values are not unusual for aqueous extracts, but those with higher values would require more caution with respect to storage and handling. The relatively high TA values $(3.79-20.68 \% \mathrm{w} / \mathrm{w})$ as against the undetectable amounts of acid insoluble ash (see Table 2), indicate a high content of physiological ash, but negligible amounts of inorganic contaminants.

The TLC results (Table 3 ) demonstrate the effectiveness of the procedures adopted in the study, since they were successfully used for the identification of the extracts and for detecting chemical impurities in them. The $P$. nitida extract, which was developed with ethylacetate-chloroform-methanol-water in a ratio of $16: 8: 4: 1$, yielded four principal spots, while the $D$. microcarpum extract, developed 
Table 3: Thin layer chromatography (TLC) of the extracts of six Nigerian medicinal plants

\begin{tabular}{lllllllll}
\hline Extract & Solvent system & $\begin{array}{l}\text { No. of } \\
\text { Spots }\end{array}$ & \multicolumn{5}{c}{ Retention factor (Rf) } \\
P. nitida & $\begin{array}{l}\text { EA:CF:Met:Water } \\
\text { (8:4:2:0.5) }\end{array}$ & 4 & 0.51 & 0.40 & 0.31 & 0.14 & \\
D. microcarpum & & 5 & 0.94 & 0.89 & 0.74 & 0.63 & 0.51 \\
A. melagueta & & 5 & 0.96 & 0.82 & 0.48 & 0.34 & 0.18 \\
T. catappa & & - & 0.90 & 0.80 & 0.46 & & \\
A. nilotica & & - & - & - & - & - & - \\
M. lucida & & 4 & 0.69 & 0.60 & 0.45 & 0.27 & \\
\hline
\end{tabular}

Note: EA represents ethyl acetate; CF, chloroform; and Met, methanol. The above results represent typical chromatograms from two or three experiments.

Table 4: Metallic content of extracts of six Nigerian medicinal plants

\begin{tabular}{|c|c|c|c|c|c|c|c|c|c|c|c|}
\hline $\begin{array}{l}\text { Metal } \\
\text { Heaviness } \\
\text { factor }\end{array}$ & $\begin{array}{l}\mathrm{Na} \\
22.3\end{array}$ & $\begin{array}{l}K \\
33.5\end{array}$ & $\begin{array}{l}\mathrm{Mg} \\
41.8\end{array}$ & $\begin{array}{l}\mathrm{Ca} \\
62.0\end{array}$ & $\begin{array}{l}\mathrm{Cr} \\
374\end{array}$ & $\begin{array}{l}\text { Mn } \\
407\end{array}$ & $\begin{array}{l}\mathrm{Fe} \\
439\end{array}$ & $\begin{array}{l}Z n \\
464\end{array}$ & $\begin{array}{l}\mathrm{Ni} \\
525\end{array}$ & $\begin{array}{l}\mathrm{Cu} \\
573\end{array}$ & $\begin{array}{l}\mathrm{Pb} \\
2352\end{array}$ \\
\hline Extract & \multicolumn{11}{|c|}{ Concentration of metallic constituents in extract $(\mathrm{mg} / \mathbf{1 0 0 g})$} \\
\hline P. nitida & 2.2 & 2.3 & 6.1 & 41 & 0.71 & 3.8 & 16 & 1.9 & 0.77 & 0.33 & 0.07 \\
\hline D. microcarpum & 2.2 & 2.1 & 5.4 & 62 & 0.96 & 7.7 & 3.9 & 1.8 & 0.40 & 0.16 & 0.09 \\
\hline A. melagueta & 2.6 & 3.1 & 4.4 & 57 & 1.2 & 18 & 40 & 5.1 & 0.44 & 0.56 & 0.05 \\
\hline T. catappa & 3.1 & 2.6 & 23 & 216 & 1.4 & 11 & 9.4 & 5.9 & 0.67 & 0.58 & 0.22 \\
\hline A. nilotica & . & - & - & - & - & - & - & - & - & - & \\
\hline M. lucida & 2.8 & 1.9 & - & 76 & 1.5 & 18 & 15 & 3.4 & 0.59 & 0.16 & 0.06 \\
\hline
\end{tabular}

Note: 'Heaviness factor' is the atomic weight of the element multiplied by its specific gravity. The results represent the mean of 2 or 3 determinations.

with ethylacetate-methanol-water in a ratio of $7: 2: 1$, yielded five spots. Similarly, the extracts of $A$. melagueta and of $T$. catappa, developed with hexane-ethylacetate in ratios of $60: 40$ and $80: 20$, yielded five and three spots, respectively. The $M$. lucida extract, developed with ethylacetate-methanol-water in a ratio of $7: 2: 1$, yielded four spots. Any additional spots not concordant with these would probably suggest the presence of impurities. The results of the metallic content analysis are shown in Table 4. Although their roles have not been investigated in this study, it is known that chromium, which is essential for glucose metabolism, was found in appreciable amounts in $P$. nitida, which is being considered for development as an antidiabetic. Similarly, zinc - which is required for the regulatory role of insulin- and nickel which collaborates with other elements to facilitate functions of the beta-cells of the pancreas, were also both present in appreciable amounts in $P$. nitida. It would seem that the presence in appreciable amounts of these metals in $P$. nitida is consistent with their supposed role in glucose metabolism which is a major issue in diabetes mellitus. A similar point can be made regarding the appreciable presence of zinc, iron, nickel and copper in the extracts of A. melagueta and T. catappa, in view of the link of these metals to the normal functioning of erythrocytes.

It interesting to note that the levels at which these metals occurred in the samples varied, in some instances, inversely, with the metal's heaviness factor - defined as the product of the metal's atomic weight and its specific gravity. For example, in $P$. nitida extract, sodium, with a heaviness factor of 22.3, occurred at a level of $2.2 \mathrm{mg} / 100 \mathrm{~g}$ while chromium, with a heaviness factor of 374 , was $0.71 \mathrm{mg} / 100 \mathrm{~g}$. In the same extract, 
potassium, with a heaviness factor of 33.5 , was $2.3 \mathrm{mg} / 100 \mathrm{~g}$ while lead, with a heaviness factor of 2352 , was $0.07 \mathrm{mg} / 100 \mathrm{~g}$. This general trend is seen in all the other extracts (Table 4). Thus, it may be that these results underlie the intricate balance that exists in nature, i.e., between the intricate metallic composition of the soil upon which the plants are raised, the biochemistry of the tissues in which the metals are selectively concentrated, and the physiological requirements of the human organs into which the same metals are differentially partitioned. This tendency probably underscores the appropriateness of using natural therapies to correct homeostatic disequilibria engendered by disease conditions such as diabetes, sickle cell anemia and malaria.

\section{CONCLUSION}

The results confirm that the extracts possess characteristics that predispose them to possible development into solid dosage forms. Furthermore, they did not present any special difficulties in handling, and their lead contents complied with official limits.

\section{REFERENCES}

1. General guidelines for methodologies on research and evaluation of traditional medicine. World Health Organization, Geneva; WHO/EDM/TRM/2000.1: 2000. 184p.

2. Wambebe, C., Khamofu, H., Momoh, J. A., Ekpeyong, M., Audu, B.S., Njoku, S. O., Nasipuri NR, Kunle OO, Okogun, Jl, Enwerem, NM, Gamaniel, SK, Obodozie, OO, Samuel, B, Fojule, G, Ogunyale PO. Double-blind, placebo-controlled, randomized cross-over clinical trial of NIPRISAN in patients with sickle cell disorder. Phytomedicine 2001; 8(4):252261. Available from: http://dx.doi.org/10.1078/ 0944-7113-00040

3. Kapadia GJ, Angerhofer CK, Ansa-Asamoah $R$. Akuammine: an antimalarial indolemonoterpene alkaloid of Picralima nitida seeds. Planta Med. 1993 Dec; 59(6):565-6.

4. Duwiejua M, Woode E, Obiri DD. Pseudoakuammigine, an alkaloid from Picralima nitida seeds, has anti-inflammatory and analgesic actions in rats. J. Ethnopharmacol. 2002; (81):73-79.

5. Lewin G, Le Ménez $P$, Rolland $Y$, Renouard $A$, Giesen-Crouse E. Akuammine and dihydroakuammine, two indolomonoterpene alkaloids displaying affinity for opioid receptors. J. Nat. Prod. 1992 Mar; 55(3):380-4.

6. Inya-Agha SI. The Hypoglycemic Properties of Picralima nitida. Nig J. Nat. Prod. Med. 1999; 3: $66-67$.

7. Salihu M. Ajao, Luqman A. Olayaki, Oshiba O. J., Rabiu O. Jimoh, Sikiru A. Jimoh, Ayokunle Olawepo and Adesola I. R. Abioye. Comparative study of the hypoglycemic effects of coconut water extract of Picralima nitida seeds (Apocynaceae) and Daoni ${ }^{\circledR}$ in alloxaninduced diabetic albino rats. Afr. J. Biotechnol. 18 February 2009; 8 (4): 574-576.

8. Aframomum melegueta. Grains of paradise. Available from: http://en.wikipedia.org/wiki/Afro momum melegueta. Accessed 2009 Jul 21.

9. Terminalia catappa. Available from: http://en.wikipedia.org/wiki/Terminalia_catappa Accessed $2009 \mathrm{Jul} 21$

9. Terminalia catappa - tropical almond. Suriname's Traditional Medicine. Available from: http://www.tropilab.com/terminaliacatappa.cat. html . Accessed 2009 Jul 21

10. Acacia nilotica. Available from: http://en.wikipedia. org/wiki/Acacia_nilotica. Accessed 2009 Jul 21.

11. Morinda lucida Benth. Protabase Record. Available from: http://database.prota.org/PROTAhtml/ Morinda\%20ucida_En.htm . Accessed 2009 Jul 21.

12. Adesida, G.A. and Adesogan, E.K. Oruwal, a novel dihydroanthraquinone pigment from Morinda lucida Benth. J. Chem. Soc.: Chem. Comm., 1972; 1: 405-406.

13. Barbara Struempler. Mineralsl minerals.htm. Available from: http://www.healthgoods.com/ Default.htm . Accessed $2009 \mathrm{Jul} 21$.

14. Healthmad. Essential Minerals. Available from: http://www.healthmad.com/Nutrition/index.382. Accessed 2009 Jul 21.

15. Narendhirakannan $R T$, Subramanian $S$ and Kandaswamy M. Mineral content of some medicinal plants used in the treatment of diabetes mellitus. Biol. Trace Elem. Res. 2005; 103(2):109-115.

16. Quality control methods for medicinal plant materials. World Health Organization, Geneva; 1998. $115 p$.

17. British Pharmacopoeia, Volume IV. The Stationery Office Limited, London. 2004. Appendix II D, Atomic spectrophotometry: emission and absorption, pp. A143-145. 